\title{
DE(s)COLAR DE CASA: \\ DILEMAS CONTEMPORÂNEOS DOS CASAIS DE \\ AERONAUTAS
}

Marilia Saldanha da Silva

O tema central desta dissertação é a questão da desigualdade de gênero na divisão de tarefas domésticas e responsabilidades familiares entre membros de casais de aeronautas, profissionais da aviação comercial (comissários e pilotos). Procura-se investigar neste subgrupo como ocorre a conciliação entre vida familiar e o trabalho de turnos alternantes. Utiliza-se como referencial importante as relações de gênero na contemporaneidade.

BANCA:

Bernardo Jablonski (Orientador)

Andrea Seixas Magalhães

Maria Lucia Rocha-Coutinho

Data da defesa: 26/02/ 2010 